\title{
Development of Vestibular Organ and Cochlea
}

\author{
Chan Ho Hwang \\ Department of otorhinolaryngology, Incheon Medical Center, Incheon, Korea
}

\section{전정기관과 와우의 발생}

황 찬 호

인천의료원 이비인후과

\author{
Address for correspondence \\ Chan Ho Hwang, MD, PhD \\ Department of Otorhinolaryngology, \\ Incheon Medical Center, \\ 159 Bangchuk-gil, Dong-gu, \\ Incheon 401-711, Korea \\ Tel $+82-32-580-6150$ \\ Fax +82-2-6455-2140 \\ E-mail chanhoh@gmail.com
}

\begin{abstract}
Inner ear is an important organ that is responsible for balance and hearing. It is composed of two complicated major subunits, vestibular organ and cochlea. During development, both functional units require complex genetic interactions to achieve proper patterning and morphology as its purpose. This review comprises three parts. In the first part, general information about technical tools in studying mouse ear development is introduced. In the second part, it is shown how semicircular canals are formed and what genetic interaction is involved in canal formation. In the last part, genetic interactions required for proper development of cochlea are elaborated, focusing on the length of cochlea and morphology of organ of Corti. The study about development of mutant mice provides us useful information about genetic interaction involved in the formation of structures for hearing and balance. The data acquired in the development field could provide a breakthrough to hair cell regeneration and stem cell therapy fields in stuck, which are directly applicable to human. Korean J Otorhinolaryngol-Head Neck Surg 2010;53:265-74
\end{abstract}

\section{서 론}

인간의 내이형성은 태생 17 19주에 성인크기에 도달하며 38주라는 인간의 재태기간을 생각한다면 내이는 매우 이른 시기에 완성됨을 알 수 있다. ${ }^{1)}$ 마우스는 인간과 매우 유사한 형태의 내이구조를 가지고 있으며 내이형성과정 또한 인간과 매우 흡사하다. 그러므로 마우스의 내이형성과정에 대한 연 구는 인간의 내이형성 과정을 분자생물학적으로 보다 심도 있게 이해할 수 있게 해주며 궁극적으로는 인간의 내이기형 에 대한 치료법 개발을 위한 좋은 실험도구로 활용될 수 있 을 것이다. 특히 유전자 변형 마우스는 내이를 형성함에 있어 유전자들의 상호작용에 대한 중요한 정보를 제공해준다.

줄기세포(stem cell)를 손상된 와우(cochlea)에 넣어주 어 손상된 유모세포(sensory hair cell)를 대체시키고자 했 던 실험들은 많은 사람들의 기대에도 불구하고 별다른 성 과를 거두지 못하였다. 손상된 내이에 대한 줄기세포치료 (stem cell therapy) 실험이 이렇게 답보를 보이는 이유 는 아직도 우리가 유모세포들의 형성에 관한 구체적인 분
자생물학적인 기전을 이해하고 있지 못하고 있기 때문으로 생각된다. 발생학(development)은 내이(inner ear)의 형성 과정 중에 보이는 유전자(gene)의 발현양상(expression)을 이해하고 유전자변형마우스(genetically modified mouse) 에서 보이는 기형(phenotype)이 생기는 기전(mechanism) 을 분석함으로써 유전자 간 상호작용(genetic interaction) 을 밝히는 학문으로 현재 답보상태에 있는 줄기세포치료 (stem cell therapy) 와 유모세포 재생연구(regeneration)에 돌파구(breakthrough)를 제공할 수 있을 것이라 기대 된다.

이 리뷰는 내이발생학에서 사용되는 연구기법에 대한 개 략적인 소개와 세반고리관의 발달, 그리고 와우성장에서 길 이와 유모세포의 수를 결정하는 유전자를 설명하는 데 초 점을 맞추었다. 인간의 몸은 선천적인 전정기관의 결손에 대해서 시운동신경이나 체신경의 보강을 통해 훌륭하게 균 형을 이루는 법을 저절로 터득하므로 세반고리관의 기형은 임상적으로는 많은 의미가 없어 보이지만 많은 선천성 난청 환자들에게서 발견되는 세반고리관의 기형형태에 대한 분 석은 난청의 원인을 발견하는 데 단서(clue)를 제공해 줄 
수 있다(Table 1). 마찬가지로 코티기관을 형성하는 데 있 어서도 수많은 유전자들이 코티기관 근처에서 발현되며, 그 유전자들이 제거되었을 경우 나타내는 와우길이의 단축과 유모세포 열의 증가나 감소는 인간의 Mondini 기형의 원인 을 밝히는 데 도움이 되리라고 생각한다(Table 2). 아직 결
론을 내릴만한 단계는 아니지만 내이성장과정에서 보이는 이러한 유전자의 발현양상과 유전자변형마우스에서 보이 는 유전자 상호작용에 대한 지식은 앞으로 유전자중심으로 재편되는 임상환경을 이해하는 데 많은 도움을 주리라 생 각한다.

Table 1. The canal phenotype of mutant mice

\begin{tabular}{|c|c|c|c|c|c|c|}
\hline \multirow{2}{*}{ Gene } & \multicolumn{3}{|c|}{ Semicircular canal phenotype } & \multirow{2}{*}{ Cristae } & \multirow{2}{*}{$\begin{array}{l}\text { Genetic } \\
\text { character }\end{array}$} & \multirow{2}{*}{ Authors } \\
\hline & Anterior canal & Lateral canal & Posterior canal & & & \\
\hline \multicolumn{7}{|c|}{ Genes expressed in canal pouch } \\
\hline Dlx5/6 & Absent & Absent & Absent & Total cristae absent & Double deletion & $\begin{array}{l}\text { Robledo and Lufkin } \\
\text { (2006) }\end{array}$ \\
\hline Dlx $5^{-/-}$ & Absent & Small & Absent & Total cristae absent & Deletion & $\begin{array}{l}\text { Acampora et al. } \\
\text { (1999) } \\
\text { Depew et al. (1999) }\end{array}$ \\
\hline $\mathrm{Hm} \times 3^{-1-}(\# 1)$ & Small & Absent & Absent & Lateral crista absent & Deletion & Hadrys et al. (1998) \\
\hline $\mathrm{Hm} \times 3^{-/-}(\# 2)$ & Normal & Normal & Normal & Lateral crista absent & Deletion & Wang et al. (1998) \\
\hline $\mathrm{Hm} \times 2^{-/-}$ & Absent & Absent & Absent & Lateral crista absent & Deletion & Wang et al. (2001) \\
\hline $\begin{array}{l}\mathrm{Hm} \times 2^{-/-} \\
\mathrm{Hm} \times 3^{-/-}\end{array}$ & Absent & Absent & Absent & Absent & Double deletion & Wang et al. (2004) \\
\hline $\mathrm{Fgf3}^{-/-}$ & Variable & Variable & Variable & $\begin{array}{l}\text { Posterior crista } \\
\text { absent }\end{array}$ & $\begin{array}{l}\text { Conditional } \\
\text { deletion }\end{array}$ & Hatch et al. (2007) \\
\hline $\mathrm{Fgf9}^{-1-}$ & Absent & Rudimentary & Absent & Normal & Deletion & Pirvola et al. (2004) \\
\hline $\mathrm{Ntnl}^{-/-}$ & Normal & Absent & Absent & Normal & $\begin{array}{l}\text { Deletion by gene } \\
\text { trap }\end{array}$ & Salminen et al. (2000) \\
\hline $\mathrm{Norl}^{-/-}$ & Thinned & Thinned & Thinned & Normal & Deletion & Ponnio et al. (2002) \\
\hline Ephrin B2 ${ }^{-/-}$ & Thinned & Thinned & Thinned & Normal & Deletion & Dravis et al. (2007) \\
\hline Lrig $^{-/-}$ & Normal & $\begin{array}{l}\text { Not resorbed, } \\
\text { Truncated }\end{array}$ & Normal & Normal & $\begin{array}{l}\text { Conditional } \\
\text { deletion }\end{array}$ & Abraira et al. (2008) \\
\hline $\begin{array}{l}\text { Lrig }^{-/-} ; \\
\text {Netrin }^{+/-}\end{array}$ & Normal & Normal & Normal & Normal & Double deletion & Abraira et al. (2008) \\
\hline $\mathrm{Bmp}^{-/-}$ & Absent & Absent & Absent & Normal & $\begin{array}{l}\text { Conditional } \\
\text { deletion }\end{array}$ & $\begin{array}{l}\text { Hwang and Wu } \\
\text { (unpublished) }\end{array}$ \\
\hline $\mathrm{Gli3}^{-/-}$ & Truncated & Absent & Narrowed & Normal & Deletion & Bok et al. (2007) \\
\hline $\mathrm{Gb} \times 2^{-/-}$ & Swollen & Unaffected & Swollen & Present & Deletion & Lin et al. (2005) \\
\hline \multicolumn{7}{|c|}{ Genes expressed in cristae } \\
\hline $\mathrm{Jagl}^{-/-}$ & Truncated & Absent & Absent & Absent & $\begin{array}{l}\text { Conditional } \\
\text { deletion }\end{array}$ & Kiernan et al. (2006) \\
\hline $\mathrm{Jagl}^{+/-}$ & Small ampulla & Small ampulla & $\begin{array}{l}\text { Truncated, } \\
\text { Missing ampulla }\end{array}$ & $\begin{array}{l}\text { Posterior crista } \\
\text { absent }\end{array}$ & Deletion & Kiernan et al. (2006) \\
\hline $\mathrm{Jag} 1^{\mathrm{Htu}} /+$ & $\begin{array}{l}\text { Absence of } \\
\text { ampulla }\end{array}$ & Normal & $\begin{array}{l}\text { Absence of } \\
\text { ampulla }\end{array}$ & Malformed & $\begin{array}{l}\text { ENU derived } \\
\text { heterozygote }\end{array}$ & Kiernan et al. (2001) \\
\hline Sox $2^{\text {Lcc/LcC }}$ & Thin, truncated & Thin, truncated & Absent & Absent & X-ray irradiation & Kiernan et al. (2005) \\
\hline $\mathrm{Sox} 2^{Y s b / Y s b}$ & Truncated & Truncated & Intact & Absent & $\begin{array}{c}\text { Fortuitous insertion } \\
\text { of a transgene }\end{array}$ & Kiernan et al. (2005) \\
\hline Fgfl10 & Not resorbed & Small, truncated & Absent & $\begin{array}{l}\text { Posterior crista } \\
\text { absent }\end{array}$ & Deletion & $\begin{array}{l}\text { Pauley et al. (2003) } \\
\text { Wu et al. } \\
\quad \text { (unpublished) }\end{array}$ \\
\hline $\mathrm{Bmp}^{-/-}$ & Absent & Absent & Absent & Total cristae Absent & $\begin{array}{l}\text { Conditional } \\
\text { deletion }\end{array}$ & Chang et al. (2008) \\
\hline Foxgl ${ }^{-1-}$ & Normal & Normal & Non resorption & $\begin{array}{l}\text { Lateral crista absent, } \\
\text { Malformed cristae }\end{array}$ & Deletion & $\begin{array}{l}\text { Pauley et al. (2006) } \\
\text { Hwang et al. (2009) }\end{array}$ \\
\hline SixlCwe/Cwe & $\begin{array}{l}\text { Thin } \\
\text { truncated }\end{array}$ & Absent & Absent & $\begin{array}{l}\text { Posterior crista } \\
\text { absent }\end{array}$ & ENU derived & Bosman et al. (2009) \\
\hline Sixl ${ }^{+/-} \mathrm{Eya}^{+/-}$ & Intact & Intact & $\begin{array}{l}\text { Truncated, } \\
\text { Missing ampulla }\end{array}$ & $\begin{array}{l}\text { Absent posterior } \\
\text { crista }\end{array}$ & Deletion & Zheng et al. (2003) \\
\hline Eya $^{+/-}$ & $\begin{array}{l}\text { Truncated, } \\
\text { missing ampulla }\end{array}$ & Intact & Intact & Absent anterior crista & Deletion & Zou et al. (2008) \\
\hline
\end{tabular}




\section{본론}

\section{발생 실험기법과 유전자변형마우스}

발생학에서 다른 연구에서보다 많이 사용되는 실험기법
은 RNA의 발현을 검출하는 in situ hybridization이다. 항 체를 만드는 생물공학의 발달로 많은 종류의 항단백질 항 체들이 인터넷상에서 구입 사용 가능하지만 항체별, 조직 별로 다른 고정(fixation) 시간이나 항원노출법(Antigen re-

Table 2. Genes related with patterning of organ of Corti

\begin{tabular}{|c|c|c|c|c|c|c|}
\hline \multirow{2}{*}{ Deleted gene } & \multirow{2}{*}{$\begin{array}{l}\text { Length of } \\
\text { cochlea duct }\end{array}$} & \multicolumn{3}{|c|}{ Cochlear phenotype } & \multirow{2}{*}{ Genetic character } & \multirow{2}{*}{ Ref. } \\
\hline & & Base & Middle & Apex & & \\
\hline \multicolumn{7}{|l|}{ Notch related } \\
\hline $\mathrm{Jag} 2^{-/-}$ & Normal & & $\begin{array}{l}4 \text { rows of } \mathrm{OHC}, \\
2 \text { rows of } \mathrm{IHC}\end{array}$ & & Deletion & $\begin{array}{l}\text { Landford et al. } \\
\text { (1999) }\end{array}$ \\
\hline $\mathrm{Lfng}^{-/-}$ & Normal & & Normal & & Deletion & Zhang et al. (2000) \\
\hline $\mathrm{Jag}^{-/-} ; \mathrm{Lfng}^{-/-}$ & Normal & & $\begin{array}{l}4 \text { rows of } \mathrm{OHC} \\
1 \text { rows of } \mathrm{IHC}\end{array}$ & & $\begin{array}{l}\text { Double } \\
\text { Knockout }\end{array}$ & $\begin{array}{l}\text { Zhang et al. } \\
\text { (2000) }\end{array}$ \\
\hline $\mathrm{Htu}^{+/-}$ & Normal & $\begin{array}{l}\text { Two rows of } \mathrm{OHC} \text {, } \\
\text { extra and } \\
\text { atypical IHC }\end{array}$ & $\begin{array}{l}\text { Two rows of } \mathrm{OHC} \text {, } \\
\text { extra and } \\
\text { atypical IHC }\end{array}$ & $\begin{array}{l}\text { Two rows of } \mathrm{OHC}, \\
\text { extra and } \\
\text { atypical } \mathrm{IHC}\end{array}$ & $\begin{array}{l}\text { Missense mutation } \\
\text { of Jagl }\end{array}$ & $\begin{array}{l}\text { Kiernan et al. } \\
\quad(2001)\end{array}$ \\
\hline $\mathrm{Cm}^{+/-}$ & Normal & $\begin{array}{l}\text { Two rows of } \mathrm{OHC} \text {, } \\
\text { extra } \mathrm{IHC}\end{array}$ & $\begin{array}{l}\text { Two rows of } \mathrm{OHC} \text {, } \\
\text { extra } \mathrm{IHC}\end{array}$ & $\begin{array}{l}\text { 4-5 rows of } \mathrm{OHCs}, \\
\text { extra } \mathrm{IHC}\end{array}$ & $\begin{array}{l}\text { Deletion } \\
\text { encompassing Jagl }\end{array}$ & $\begin{array}{l}\text { Kiernan et al. } \\
\quad(2001)\end{array}$ \\
\hline Hesl ${ }^{-/-}$ & Normal & & 2 rows of $I H C$ & & Deletion & Zine et al. (2001) \\
\hline Hes $5^{-/-}$ & Normal & & 4 rows of $\mathrm{OHC}$ & & Deletion & Zine et al. (2001) \\
\hline DIII ${ }^{-/-}$ & Normal & $\begin{array}{l}4 \text { rows of } \mathrm{OHC} \\
\text { increased } \mathrm{IHC}\end{array}$ & $\begin{array}{l}4 \text { rows of } \mathrm{OHC} \\
\text { increased } \mathrm{IHC}\end{array}$ & Increased HC & Conditional deletion & $\begin{array}{l}\text { Brooker et al. } \\
\quad(2006)\end{array}$ \\
\hline $\mathrm{Jagl}^{-/-}$ & Normal & $\begin{array}{l}\text { OHC missing, } \\
\text { disorganized } \\
\text { rows and islets } \\
\text { of IHC }\end{array}$ & $\begin{array}{l}\text { OHC missing, } \\
\text { disorganized rows } \\
\text { and islets of IHC }\end{array}$ & Reduced HC & Conditional deletion & $\begin{array}{l}\text { Brooker et al. } \\
\quad(2006)\end{array}$ \\
\hline \multicolumn{7}{|c|}{ Convergent extension and PCP pathway related } \\
\hline Vangl $^{-/-}$ & Short & $\begin{array}{c}\text { Normal in rows of } \\
\mathrm{OHC} \text { and } \mathrm{IHC}\end{array}$ & $\begin{array}{l}\text { Increased HC } \\
\text { toward apex }\end{array}$ & $\begin{array}{l}>4 \text { rows of } \mathrm{OHC} \\
>2 \text { rows of } \mathrm{IHC}\end{array}$ & Deletion & $\begin{array}{c}\text { Montcouquiol } \\
\text { et al. (2003) }\end{array}$ \\
\hline Scrbl ${ }^{-1-}$ & Not specified & & $\begin{array}{l}\text { Mis-oriented } 2 \text { nd, } \\
3 \text { rd rows of } \mathrm{OHC}\end{array}$ & & Deletion & $\begin{array}{l}\text { Montcouquiol et } \\
\text { al. (2003) }\end{array}$ \\
\hline $\mathrm{Dvll}^{-/-} ; \mathrm{Dvl} 2^{-/-}$ & Short & $\begin{array}{c}\text { Normal in rows of } \\
\mathrm{OHC} \text { and } \mathrm{IHC}\end{array}$ & $\begin{array}{c}\text { Normal in rows of } \\
\mathrm{OHC} \text { and } \mathrm{IHC}\end{array}$ & Increased $\mathrm{OHC}$ & $\begin{array}{l}\text { Double } \\
\text { deletion }\end{array}$ & Wang et al. (2003) \\
\hline Wnt5a $a^{-1-}$ & Short & 4 rows of $\mathrm{OHC}$ & & $4-5$ rows of $\mathrm{OHC}$ & Deletion & Qian et al. (2007) \\
\hline Myo $^{-/-}$ & Short & $\begin{array}{l}>2 \text { rows of pillar } \\
\text { cells }\end{array}$ & $\begin{array}{l}>2 \text { rows of pillar } \\
\text { cells }\end{array}$ & $\begin{array}{l}>2 \text { rows of pillar } \\
\text { cells }\end{array}$ & $\begin{array}{l}\text { Conditional deletion } \\
\text { of Myh10 }\end{array}$ & $\begin{array}{l}\text { Yamamoto et al. } \\
\text { (2009) }\end{array}$ \\
\hline \multicolumn{7}{|l|}{ Fgfs related } \\
\hline Fgfr $1 \mathrm{n} 7 / \mathrm{n} 7$ & Normal & 2 rows of $\mathrm{OHC}$ & 2 rows of $\mathrm{OHC}$ & 2 rows of $\mathrm{OHC}$ & $\begin{array}{l}\text { Hypomorphic } \\
\text { conditional deletion }\end{array}$ & Pirvola et al. (2002) \\
\hline Fgfrl $^{-/-}$ & Normal & $\begin{array}{l}\text { OHC patches, } \\
\text { Sparse IHC, } \\
\text { Pillar cell Cluster }\end{array}$ & $\begin{array}{l}\text { OHC patches, } \\
\text { Sparse IHC, } \\
\text { Pillar cell Cluster }\end{array}$ & $\begin{array}{l}\text { OHC patches, } \\
\text { Sparse IHC, } \\
\text { Pillar cell Cluster }\end{array}$ & Conditional deletion & Pirvola et al. (2002) \\
\hline $\mathrm{Fgf9}^{-/-}$ & Normal & Normal & Normal & Normal & Deletion & Pirvola et al. (2004) \\
\hline $\mathrm{Fgfr}^{-/-}$ & Normal & $\begin{array}{l}4 \text { rows of } \mathrm{OHC} \\
\text { rack of pillar cell } \\
\text { differentiation }\end{array}$ & $\begin{array}{l}4 \text { rows of } \mathrm{OHC} \\
\text { rack of pillar cell } \\
\text { differentiation }\end{array}$ & $\begin{array}{l}4 \text { rows of } \mathrm{OHC} \\
\text { rack of pillar cell } \\
\text { differentiation }\end{array}$ & Deletion & $\begin{array}{l}\text { Puligilla et al. (2007) } \\
\text { Hayashi et al. } \\
\quad \text { (2007) }\end{array}$ \\
\hline $\mathrm{Fgfl}^{-/-}$ & Normal & $\begin{array}{l}\text { Rack of pillar cell } \\
\text { differentiation }\end{array}$ & $\begin{array}{c}\text { Rack of pillar cell } \\
\text { differentiation }\end{array}$ & $\begin{array}{l}\text { Rack of pillar cell } \\
\text { differentiation }\end{array}$ & Conditional deletion & $\begin{array}{l}\text { Jacques et al. } \\
\text { (2007) }\end{array}$ \\
\hline Fgf20 & $\begin{array}{l}\text { Cochlear } \\
\text { Explants }\end{array}$ & & $\begin{array}{l}\text { Decreased hair } \\
\text { cells and } \\
\text { supporting cells }\end{array}$ & & Blocking $\mathrm{Ab}$ & $\begin{array}{l}\text { Hayashi et al. } \\
\text { (2008) }\end{array}$ \\
\hline \multicolumn{7}{|c|}{ Genes not included above criteria } \\
\hline Foxgl $^{-1-}$ & Short & 4 rows of $\mathrm{OHC}$ & $\begin{array}{l}5-6 \text { rows of } \mathrm{OHC} \\
2-3 \text { rows of } \mathrm{IHC}\end{array}$ & $\begin{array}{l}\text { To } 6 \text { rows of } \mathrm{OHC} \text {, } \\
\text { to } 3 \text { rows of } \mathrm{IHC}\end{array}$ & Deletion & $\begin{array}{l}\text { Pauley et al. } \\
\text { (2006) }\end{array}$ \\
\hline Gli34699/699 & Short & $\begin{array}{c}\text { At least one extra } \\
\text { rows of } \mathrm{OHC}\end{array}$ & $\begin{array}{c}\text { To } 7 \text { extra rows } \\
\text { of } \mathrm{OHC}\end{array}$ & $\begin{array}{l}\text { At least one extra } \\
\text { rows of } \mathrm{OHC}\end{array}$ & Truncated deletion & Driver et al. (2008) \\
\hline $\mathrm{Shh}^{-/-}$ & Short & $\begin{array}{l}4 \text { rows of } \mathrm{OHC} \\
\text { increased } \mathrm{IHC}\end{array}$ & $\begin{array}{l}\text { Extra rows to } 7 \text { of } \\
\text { OHC, } 2 \text { rows of } \mathrm{IHC}\end{array}$ & $\begin{array}{l}4 \text { rows of } \mathrm{OHC}, \\
\mathrm{C} 2 \text { rows of } \mathrm{IHC}\end{array}$ & $\begin{array}{l}\text { Conditional } \\
\text { deletion }\end{array}$ & $\begin{array}{l}\text { Wu et al. } \\
\text { (unpublished) }\end{array}$ \\
\hline
\end{tabular}


trieval method), 백그라운드(background noise) 문제 등 좋은 시그날을 얻기 위해 많은 시간과 노력을 요하며, 또한 사용가능한 항체의 수에 제한이 있고 비용 또한 비싼 단점 이 있다. 반면 in situ hybridization은 RNA probe의 종류 에 관계없이 일정한 조건에서 비교적 신뢰성 있는 시그날을 보여주며 백그라운드가 적고 목표유전자(target gene)의 서열(sequence)만 안다면 저렴한 가격에 최소한의 노력 으로 RNA probe를 재생산할 수가 있어 발생학 분야에서 없어서는 안될 강력한 실험기법 중의 하나이다. 특히 태어 나기 전의 마우스 태아는 측두골의 골화가 아직 진행되지 않아 탈석회화(decalcification)의 과정이 필요없어 in situ hybridization을 하기에 아주 적당하다.

내이의 발달을 보기 위해 검체로는 주로 어류(Zebra fish), 조류(chicken), 마우스가 주로 사용되며, Zebra fish와 chicken의 경우 morpholino와 plasmid electrophoration 같은 유전자변형기법을 이용하면 유전자를 쉽게 조작(manipulation)할 수 있고 그 결과를 수주 내에 확인할 수 있 다는 장점이 있다. Zebra fish와 chicken에서 얻어진 결과 들은 in vitro 실험 결과보다 더 신뢰할만하고 우수하지만 실제로 인간에게 적용되기에 위해서는 마우스에서 먼저 증 명이 되어야만 한다. 마우스는 사람과 유사한 유전자구조 와 내이구조를 갖고 있어 사람에서 불가능한 유전자 조작 실험이 가능하며 두개 이상의 유전자이상을 가지고 있는 복 합변형유전자마우스(compound mutant mouse)를 이용하 면 유전자의 결손으로 인한 표현형의 구제(rescue) 가능여 부까지 시험할 수 있어, 사람에게 유전자치료를 시행하기에 앞서 행하는 마우스모델을 이용한 구제(rescue)실험은 임 상적으로도 큰 의미를 지닌다. 마우스를 이용한 실험기법 으로는 유전자변형마우스(mutant mouse), 와우배양체(cochlear explant), 임신중 태아수술 등이 있다.

유전자변형마우스(mutant mouse)에는 크게 transgenic, knockout, conditional knockout 마우스로 나눌 수 있으 며 transgenic 마우스는 특정 promotor에 의해 발현되는 유전자 construct을 genomic DNA에 무작위적(random) 으로 삽입(insertion)시켜 유전자의 과잉발현(overexpression)이나 이소발현(ectpic expression)을 보고자 할 때 사용된다. Knockout out 마우스는 일반적으로 특정유전자 가 결손되어 있는 마우스를 지칭하며, 만들어지는 방법에 따라 simple knockout, knock-in, ENU (ethyl-nitrosourea), gene-trap 마우스 등으로 나눌 수 있다. Knock-in 마우스는 어떤유전자를 promoter를 남기고 제거한 다음 그 자리에 cre나 LacZ같은 다른 유전자를 삽입한 마우스 이다. ENU 마우스는 alkylating agent를 사용하여 rando- mized point mutation을 일으켜 생성되는 마우스이며, genetrap 마우스는 gene trap vector를 무작위적으로 넣어서 만들어지는 마우스로 gene trap vector가 삽입된 부위가 추적가능하다는 점이 $\mathrm{ENU}$ 마우스와는 다른 점이다. 생존에 필수적인 유전자 즉, 심장이나 혈관 등에서 발현되는 유전 자들이 제거될 경우 내이가 발생하기도 전인 태생 (embryonic day: E) 11.5일 이전에 죽기 때문에 그 유전자가 내 이형성에 미치는 영향을 분석하지 못하는 단점이 있다. 이 경우 특정조직에서만 유전자가 제거되는 conditional knockout 마우스를 이용하면 분석이 가능해진다. Conditional knockout 마우스는 특정 조직에서 발현되는 유전자의 promotor에 의해 cre recombinase가 발현되도록 만든 knockin 마우스와, 목표유전자(target gene)의 양측에 lox 유전 자를 붙인 마우스와 교배하여 cre-lox recombination으 로 목표유전자를 제거함으로써 만들어진다. 주로 Foxg1cre나 Pax2-cre 마우스가 내이 conditional knockout 마 우스를 만들 때 사용되어진다. 예를 들면 $\mathrm{Foxg} 1^{2)}$ 의 promotor에 cre가 발현되는 마우스 $\left(\mathrm{Foxg} 1^{\mathrm{cre} /+}\right)$ 와 $\mathrm{Bmp} 2^{+/-}$ 마우스를 교배하여 Foxg $1^{\mathrm{cre} /+} ; \mathrm{Bmp} 2^{+/-}$compound mutant 마우스를 만든 다음 이를 다시 $\mathrm{Bmp} 2^{\operatorname{lox} / 10 x}$ 마우스와 교 배하여 나오는 Foxg1 $1^{\mathrm{cre} /+} ; \mathrm{Bmp} 2^{\mathrm{lox} /-}$ 유전형을 가지는 마 우스가, 내이에서만 Bmp2가 제거된 conditional knockout 마우스이다(Fig. 1). Bmp2 knockout 마우스는 심장의 이상으로 E9.5경에 자궁 내에서 죽으나 conditional knockout 마우스는 태어날 때까지 생존할 수 있어 Bmp2가 제 거된 내이의 상태를 분석하는 것이 가능해진다. ${ }^{3)}$

와우배양체(cochlear explant)는 E13.5에 와우(cochlea)를 분리하여 플레이트에 배양하는 방법으로 유모세포 와 관련된 유전자조작을 쉽게 할 수 있으며 유모세포에 영 향을 미치는 다양한 약물의 효과도 빠른 시일내에 알 수 있어 최근에 각광받는 in vitro 실험 기법으로 Matthew Kelley 등이 주로 사용하고 보고하였다. ${ }^{4)}$ 마우스 임신중 태아

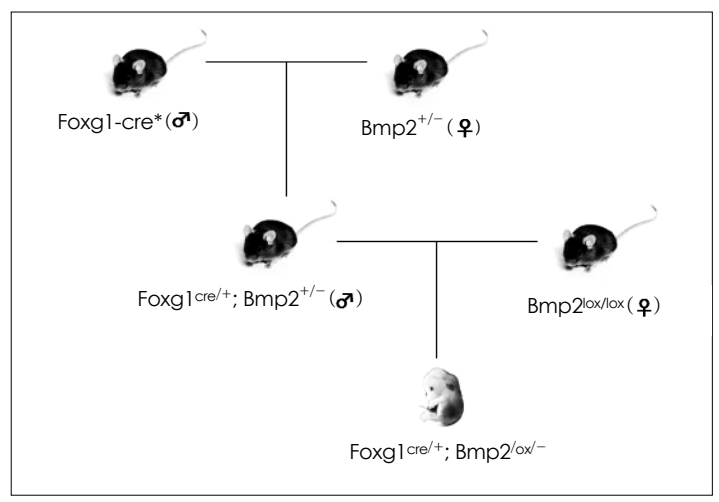

Fig. 1. Pedigree to produce Bmp2 conditional knockout mouse. 
수술은 John Brigande에 의해 소개된 방법으로 마우스 자 궁내 태아내이에 plasmid electrophoration을 시행하여 유 전자 조작을 하는 방법으로 인간의 선천성기형에 대한 유전 자치료에 한걸음 더 접근했다는 평가를 받고 있다.5) 그외 귀의 신경분포(innervation)을 추적할 수 있는 liphophilic dye tracing 기법이 있으며 Bernd Fritzsch에 의해 주로 사용되어 유전자변형마우스에서 신경분포의 이상에 대한 많 은 정보를 얻을 수 있게 되었다. ${ }^{6)}$

\section{정상 세반고리관의 발생}

마우스는 평균적으로 $\mathrm{E} 19.5$ 째에 출생하며 중요한 내이 구조물은 E11.5에서 E13.5 사이에 형성된다. 마우스 내 이는 이판(otic placode, E8.5)이라고 불리는 외배엽의 두 꺼워진 상피세포로부터 발생하여, 점차 안쪽으로 함몰되어 이배(otic cup, E9.5)라는 컵 모양의 구조를 이룬 다음 피 부 외배엽 상피로부터 완전히 분리되어 독립적인 이낭 (otocyst, E10.5)을 형성하다. ${ }^{7}$ 태생 11.5일에는 이낭의 내측(medial) 에 등측(dorsal) 으로 뺃는 내림프관(endolymphatic duct)이 뚜렷하게 관찰되며 이낭의 배측(ventral) 으로는 원시와우관(cochlear anlage)이 아래로 자라 내려 간다. 이 시기에 이낭의 등측(dorsal)으로는 수직주머니 (vertical pouch)와 평형주머니(horizontal pouch)가 형 성되는데 수직주머니는 앞반고리관(anterior semicircular canal, SCC) 과 후반고리관 (posterior SCC)으로 분화되고, 평형주머니는 외측반고리관(lateral $\mathrm{SCC}$ )으로 발생한다. $\mathrm{E} 11.75$ 에는 관주머니(canal pouch) 가 편평해지면서 서 로 마주보는 관판(canal plate)을 형성하는데, E12에는 이 들 두개의 상피세포층이 가운데서 서로 만나 한층의 융합 판(fusion plate)을 형성한다(Fig. 2). 이때 이낭의 외측에 있는 세포층의 기저막(basement membrane)이 먼저 소 실되며 맞닿은 두층의 세포들은 상호삽입(intercalated) 되 어 한층의 상피세포층을 이룬 후에 반고리관을 형성하는 가 장자리를 남기고는 점차 사라진다. ${ }^{8)}$ 이 과정은 앞반고리관 에서 먼저 시작되어 후반고리관 그리고 외측반고리관 순으 로 진행된다. $\mathrm{E} 13.5$ 에는 성인형태의 완성된 세반고리관이 관찰되며 그 이후엔 크기성장만이 진행된다.

\section{세반고리관 형성의 기전에 대한 세 가지 가설}

$\mathrm{E} 11.5$ 일에서 13.5일 사이에 반고리관 형성을 위한 이 낭의 형태학적인 변화는 관판의 함몰(indentation of canal plate), 융합(fusion of two apposing epithelial layers), 그리고 융합판 세포의 사라짐 (clearing of fusion plate cel1s) 의 세 단계로 이루어진다(Fig. 2). ${ }^{8)} \mathrm{E} 11.5$ 일에 앞관판

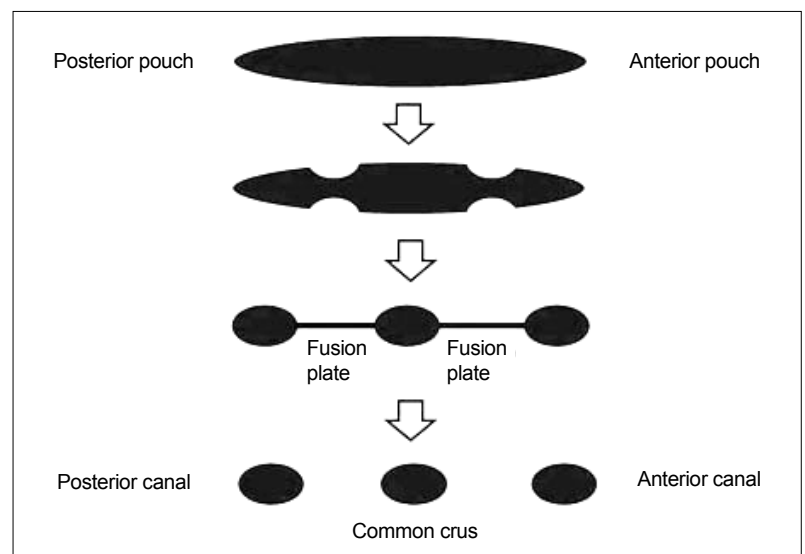

Fig. 2. Schematic diagram showing the sequence of semicircular canal formation.

(anterior canal plate)의 함몰이 시작되어 두개의 마주보 는 상피층들이 가운데서 서로 만나게 되는데 이러한 형태의 변화는 다른 기관의 발달, 즉 심장의 형성 (endocardiac cushion formation)이나 신경관이 닫힐 때(closure of neural tube), 그리고 구개(palate)의 형성 때도 마찬가지로 관찰 되는 현상이다. ${ }^{9-11)}$ 이들 조직에서는 hyaluronan의 생성이 간여하는 것으로 생각되며, 기저막의 소실(disruption of basal lamina) 과 상피세포의 재배열 (epithelial rearrangement)이 함께 일어나는 것으로 보고되어 있다. 양서류(Xenopus)에서 hyaluronidase가 이낭에 주입될 경우 관판의 함몰이 소실되는 것으로 보아 국소적이고 비대칭적으로 축 적된 hyaluronan이 관판 함몰의 주된 기전으로 생각되어진 다. ${ }^{12)}$ 실제로 마우스에서 기저막(basement membrane, $\mathrm{BM}$ ) 의 소실과 함께 많은 양의 hyaluronan이 태생 E12.5 부근에 합성되는 것으로 보고되어 있어 hyaluronan의 비 대칭적 생산이 관판 함몰의 주된 기전으로 생각된다. ${ }^{13)}$ 보 다 확실한 분자생물학적인 증거를 얻기위해서는 hyaluronan synthetase를 만드는 데 관여하는 Has1-3 유전자의 발 현을 $\mathrm{E} 11.5$ 이낭(otocyst)에서 보는 것이 도움이 될 것이 다. ${ }^{14)}$ 앞관판의 중심부가 함몰되기 시작할 때 관판 외측의 기저막 $(\mathrm{BM})$ 이 먼저 붕괴되는데, 특이하게도 융합판을 형 성할 때까지도 관판 내측의 기저막 $(\mathrm{BM})$ 은 그대로 유지된 다(Martin and Swanson, 1993). 이러한 비대칭적인 기저 막의 붕괴는 융합판세포의 운명 (fate) 과 밀접히 관련되어 있는 것으로 보인다.

융합판(fusion plate)을 이루는 단층의 세포들이 어떻게 제거되는지에 대해서는 사람이나 마우스에서 아직 확실하 게 알려져 있지 않으며 이들 상피세포들의 운명에 대해서 는 세포고사(programmed cell death), 중간엽세포로 전 환(transformation into mesenchymal cells), 반고리관 
형성에 참여(recruited back into a canal) 등의 세 가지의 가설이 존재한다. 양서류(Xenopus), 조류(avian), Zebrafish에서는 포유류와 매우 비슷한 형태의 세반고리관이 존 재하며 융합판세포가 사라질때 많은 TUNEL 양성세포가 관찰된다. ${ }^{12,15,16)}$ 하지만 마우스와 사람에서는 여러 시도에 도 불구하고 TUNEL 양성세포가 융합판세포 부위에서 발견 되지 않으므로 세포고사(apoptosis) 외에 다른 기전이 더 관 여할 것으로 생각된다. 상피세포-중간엽전환(Epithelialto-mesenchymal transformation, EMT) 은 내이상피세 포가 중간엽세포들로 전환분화되는 것을 의미하는데, 실제로 신경능선세포(neural crest cell) 들은 외엽세포(ectoderm) 에서 발생하여 중간엽세포(mesoderm)로 분화되기도 하 므로 마우스와 사람에서 융합판세포의 사라짐을 설명하기 에 매력적인 가설이다. 마주보는 두 개의 상피세포층(epithelial layers)이 융합되기 전에 외측 상피층의 기저막 붕 괴가 일어나는 현상은 EMT의 가능성을 강하게 암시한다. 실제로 $\mathrm{EMT}$ 가 조류에서 부분적으로 융합세포의 사라짐 에 관여함이 분자생물학적으로 보고된 바 있다. ${ }^{17)} 1993$ 년 에 Martin과 Swanson은 융합판세포들이 바깥쪽으로 이동 하여 세반고리관 형성에 관여한다는 가설을 제시하였는데, 이들은 Monastral Blue $(\mathrm{MB})$ 를 태생 11.5일에 이낭에 주사하여 1 일간 배양한 다음 대부분의 $\mathrm{MB}$ 염색 세포들이 흡수영역(resorption domain)이나 중간엽(mesoderm)보 다는 세반고리관 쪽에서 관찰되었음을 보고하였다. ${ }^{8)}$ 이 결과 는 융합판 형성 세포들이 세포고사나 EMT보다는 세반고리 관쪽으로 이동하여 세반고리관 형성에 참여함을 시사한다. 위에서 제시한 세 가지의 가설들은 결론을 짓기에는 아직 분 자생물학적인 증거가 부족하다. 보다 확실한 결론을 내리기 위해서는 흡수대(resorption domain)에 발현되는 유전자인 Netrin1-cre+와 ROSA 마우스의 교배를 통해 얻어지는 reporter 마우스를 이용한 세포추적(fate mapping) 연구가 필요하다. 이 reporter 마우스에서는 한번이라도 Netrin1 을 발현한 세포는 계속해서 LacZ를 발현하므로 흡수영역 대(resorption domain)에서 LacZ를 발현하기 시작한 세 포들의 이동경로를 추적하기만 하면 융합판세포 사라짐의 기전을 알 수 있을 것이다.

\section{마우스 코티기관의 정상 발생과 Bone Morphogenic Protein}

포유동물의 코티기관(organ of Corti)은 1열(row)의 내 유모세포( $\mathrm{IHC})$ 와 3열의 외유모세포 $(\mathrm{OHC})$, 그리고 pillar cell이나 Deiters' cell 같은 여러 종류의 특성화된 지지세포 로 구성된다. 코티기관은 신경외측(aneural side)으로 Hensen's and Claudius' cells가 stria vascularis와 접하고

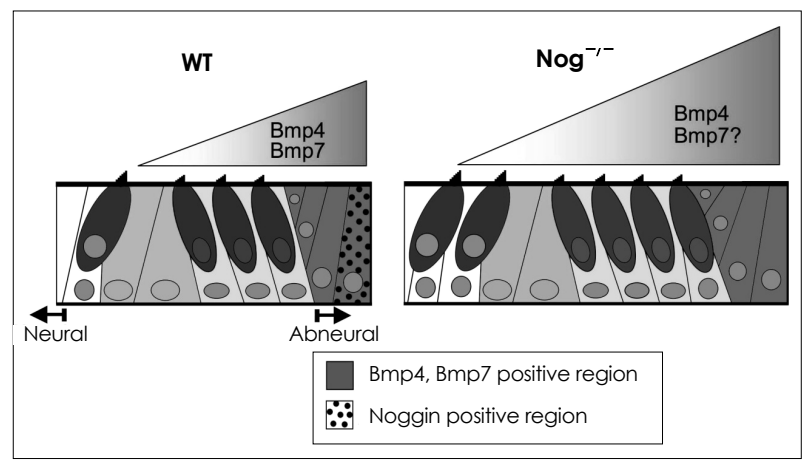

Fig. 3. The expression pattern of Bmp4/7 and Noggin during the development of organ of Corti. Bmp4 /7 are expressed in abneural side of organ of Corti making a gradient. The expression domain of Noggin is overlapped with Bmp domain. In $\mathrm{Nog}^{-/-}$, the number of hair cell row is increased, maybe due to increased activity of Bmps.

있으며 Bmp4와 Bmp7, 그리고 Noggin $(\mathrm{Nog})$ 은 이 부위 에서 강하게 발현(expression)이 된다(Fig. 3). 와우(cochlea)는 E10.75경에 이낭(otocyst)의 배측(ventral side)에 서 자라나오기 시작하여, E12.5경에 전구감각세포대(prosensory domain)를 형성하고, 그 안에 있는 세포들은 와우첨부 (apex)부터 기저부(base)쪽으로 점차 세포주기 (cell cycle)에서 빠져나오기 시작하면서 p27Kip1을 발현한다. 와 우첨부(apex)부터 시작된 p27Kip1의 발현 wave가 와우 기저부(base)에 도달하면 Math1이 와우기저부(base)에 서 발현되기 시작하며, 그 또한 와우첨부(apex)로 이동하는 wave 형태의 발현양상을 보여준다. ${ }^{18)}$ 전구감각세포대(prosensory domain)에 있는 여러 세포들은 Math1과 p27Kip1 외에도 다양한 유전적인 분화와 상호작용을 통하여 코티기 관을 형성하게 된다. ${ }^{19,20)}$

Bone morphogenetic protein (Bmp)은 세포에서 만들어 져서 세포 외로 분비되어 작용하는 신호단백(excretory protein)이며 사지, 심장, 신장, 뇌, 눈 등 여러 기관의 형성에 중 요한 역할을 한다. Bmp은 Bmp 특이 수용체에 결합함으로 써 세포질에 존재하는 Smad 1/5/8단백질을 인산화(phosphorylation)시키고 $\operatorname{Smad} 4$ 와 결합한 후 핵으로 이동하 여 Bmp 목표유전자(target gene)를 활성화시키거나 억제 한다. ${ }^{21)} \mathrm{Bmp}$ 의 활성도는 Noggin and Chordin 같은 Bmp 길항단백질 (antagonist)의 양에 따라 조절된는 것으로 알 려져 있으며,2) $\mathrm{Bmp}$ 단백과 직접 결합하거나 $\mathrm{Bmp}$ 가 수용 체에 결합하는 것을 방해하는 것으로 알려져 있다. ${ }^{23,24)}$ 실 제로 Noggin knockout $\left(\mathrm{Nog}^{-1-}\right)$ 마우스는 Bmp기능의 증 강 (gain-of-function)이라는 측면에서 Bmp를 연구하는 동물모델로서 널리 사용되어지고 있으며, ${ }^{25,26)}$ 중이의 발생 연구에서 Nog heterozygote 마우스가 이소골 형성시 새 궁(branchial arch)의 분리장애(failure of separation)로 
선천성 등골고정(stapes fixation)이 생길 수 있음이 보고 된 바 있다. ${ }^{27)}$

\section{수렴확장(Convergent extension)과 평면세포극성(planar cell polarity)}

와우관은 E10.75경에 이낭의 배측으로부터 나타나기 시작하여, 그 길이가 길어질수록 나선구조를 형성하기 시 작하여 E13.5에 1/2회전, 그리고 E16.5에 1과 3/4회전 의 구조를 갖게된다. ${ }^{7)}$ 와우관의 길이성장과 코티기관의 형 성(patterning)은 ‘수렴확장' (convergent extension)의 과정 즉, 길이 축으로는 길어지고 그 폭은 좁아지는 과정 을 통하여 만들어진다고 생각된다. ${ }^{28-31)}$ 그리하여 전구감각 세포대(prosensory domain)는 E13.5에 6 7층 세포로 구 성되었다가 점차 얇아져서 최종적으로 2 개의 세포 층을 가진 코티기관으로 성장한다. ${ }^{31)}$ 한편 평면세포극성(planar cell polarity)을 결정하는데 관여하는 유전자들, 예를들면 Vangl2, Scrb1, Dvl, Wnt5 등이 와우관의 길이성장과 유모세포의 배열에도 영향을 미친다고 알려져있다(Table 2) ${ }^{31-34)}$ 이러 한 유전자들에 결함이 있을 경우에는 유모세포 섬모의 배 열이 불규칙해질뿐만 아니라 와우첨부에 conversion extension을 하지 못한 유모세포이 많이 모여있는 짧은 와우 관이 형성된다. ${ }^{35)}$

\section{코티기관의 형성에 있어 Noggin과 Bmp의 역할}

Noggin은 Bmp와 마찬가지로 세포외로 분비되어 $\mathrm{Bmp}$ 나 $\mathrm{Bmp}$ 수용체에 경쟁적으로 결합하여 $\mathrm{Bmp}$ 의 활동을 억제 하는 신호단백이다. $\mathrm{Nog}^{-/}$마우스의 와우관(cochlear duct) 은 짧아져 있지만 평면세포극성(planar cell polarity)은 정상이며, ${ }^{3)} \mathrm{Nog}^{-/-}$마우스의 짧은 와우관은 발생초기 후뇌 (hindbrain)와 이낭 (otocyst)의 부정배열 (misalignment) 때문인 것으로 알려져 있다. ${ }^{36)}$ Noggin은 hindbrain에서 발 생초기에 강하게 발현되므로, hindbrain에서 분비되어 내 이에 영향을 미치는 신호전달단백(signaling molecule)의 발현에 영향을 줄 것으로 생각되며 hindbrain와 otocyst의 부정배열 (misalignment) 도 이에 기인하는 것으로 생각된 다. 와우의 성장장애를 보이나 평면세포극성 (planar cell polarity)은 정상을 보이는 경우는 Noggin 마우스 외에 Gli3 and Lmx1a knockout 마우스 등이 있다. ${ }^{4,37)}$

$\mathrm{Nog}^{-/-}$마우스에서는 외유모세포 $(\mathrm{OHC})$ 와 내유모세포 (IHC)의 증가와 함께 와우관의 길이가 짧아져있으며 상대적 으로 내유모세포(IHC)가 더 많이 증가되어있다(Fig. 3). ${ }^{3)}$ 일반적으로 와우 길이성장을 보이는 즉 수렴확장(convergent extension) 장애를 보이는 유전자변형마우스들은 와우 첨부(apex)에서의 외유모세포 $(\mathrm{OHC})$ 의 증가를 특징으로 한다. $\mathrm{Nog}^{-1}$ 마우스에서 보이는 유모세포 열(row)의 증가 는 와우관의 길이성장의 장애 때문일 수 있지만 내유모세포 (IHC)가 중간회전(middle) 과 첨부회전(apex)에서 외유 모세포 $(\mathrm{OHC})$ 보다 더 증가하는 경향을 보이는 것은 길이 성장의 장애만으로 쉽게 설명되지 못하는 부분이 있다. 이 로부터 유추해보면 Noggin는 코디기관의 방사상모양형성 (radial patterning) 즉, 유모세포(OHC \& IHC) 열(row)의 개수를 결정하는 데 관여함을 알 수 있다. 이것은 와우에서 $\mathrm{Nog}$ 과 Bmps의 발현양상과 관련과도 밀접한 관련이 있는데 $\mathrm{Bmp} 4, \mathrm{Bmp} 7, \mathrm{Nog}$ 의 유전자 발현대(expression domain)는 코티기관의 신경외측(abneural side)에 위치해있 으며 Bmp2만이 유모세포에서 발현된다. ${ }^{3)}$

내이 유모세포 성장에 있어 Bmp와 Noggin의 역할에 대한 몇몇 in vitro 연구들이 있으나 흥미롭게도 이들 중에 는 서로 정반대의 결과를 내는 경우도 있다. 몇몇 보고에 서 Bmp4는 마우스 와우배양(cochlear explant)이나 조류 (chicken)의 이낭세포배양(cultures of dissociated otic epithelial cells)에서 유모세포 분화(differentiation of hair cell)를 유도(induction) 한다고 하였다. ${ }^{38,39)}$ 하지만 비슷한 조건에서 시행한 연구가 정반대의 결과를 보여 조류(chicken) 이낭세포배양에서 오히려 Noggin에 의해서 유모세포 로의 분화가 유도되고 $\mathrm{Bmp}$ 에 의해서는 억제된 적이 있었 다. ${ }^{40)} \mathrm{Bmp} 4$ 는 기존 논문들에서 sensory fate와 nonsensory fates를 둘 다 촉진시킨다고 알려져 있으므로, ${ }^{41)}$ 외부에서 주어진 Bmp4가 non-sensory fate를 촉진하여 유모세포의 소실(loss)을 유도할 가능성은 존재한다. 하지 만 조류(Chicken) 이낭세포배양실험의 결과가 서로 배치 되는 반면 ${ }^{38)}$ 와우 explant 실험 결과는 Bmps가 유모세포 형성을 촉진한다는 것을 확실하게 보여준다. ${ }^{39)}$ 이 실험 결 과들은 Bmps와 Noggin의 발현대(expression domain)가 서로 인접해있고 $\mathrm{Nog}^{-/-}$마우스에서 유모세포의 줄(row) 이 증가하는 것은 Bmps와 Noggin이 코티기관의 radial patterning에 관여하기 때문이라는 가정(hypothesis) 과 일 치한다. 두개의 gain-of-Bmp function 모델인 와우배양 (explant)과 $\mathrm{Nog}^{-/}$마우스의 표현형(phenotype)의 차 이점은 $\mathrm{Nog}^{-/-}$마우스의 경우 내유모세포(IHC) 과 외유모 세포 $(\mathrm{OHC})$ 가 다 증가하고, $\mathrm{Bmp} 4$ 처리한 와우배양체 (explant)의 경우는 외유모세포 $(\mathrm{OHC})$ 만 증가한다는 것이 다. ${ }^{39)}$ Noggin은 정상적으로 E13.5일부터 와우에서 발현 되는데 와우배양체 (explant) 에서 내유모세포(IHC)의 갯수 에 변화가 없는 것은 외부에서 $\mathrm{Bmp} 4$ 가 주어진 시점에 따 른 차이 때문으로 생각된다. 
최근의 preliminary report를 보면 Bmp receptor Ia conditional knockout 마우스가 거울구조의 2중으로 된 코티 기관(duplicated organ of Corti)을 가지는 것이 보고된 바 있다(T. Ohyama and A.K. Groves; personal communication). 그래서 그 저자들은 코티기관의 발생에 있어 $\mathrm{Bmp}$ 의 농도경사(gradient)가 가장 중요한 요인이라고 주장하 였다. 이러한 Bmp의 농도경사는 Noggin에 의해서도 조절 되지만 Bmp receptor knockout 마우스와 $\mathrm{Nog}^{-/}$마우스 의 표현형은 서로 반대가 아니므로 Bmp와 Noggin이 코티 기관을 만드는 데는 뭔가 더 복잡한 기전이 있을 것으로 예 상된다. Bmps가 와우성장에서 두 가지 역할(dual action) 을 한다고 가정을 한다면 이들 두 표현형은 설명될 수 있 다. 즉, $\mathrm{Bmp}$ 의 초기 역할은 Bmp receptor knockout 마우 스에서 보이는 것 같이 감각기관분화(sensory organ specification) 억제에 있고, 이와는 반대로 $\mathrm{Nog}^{-/}$마우스나 Bmp4 treated cochlear explants에서 보이는 유모세포 의 증가촉진은 후기 역할이라고 가정한다면 설명은 가능 해진다. 이 가설은 $\mathrm{Nog}$ 의 발현이 태생 중기인 E13.5일까 지 와우에서 발견되지 않는다는 사실과도 일치한다.

\section{유모세포형성과 청각능력에서 $\mathrm{Bmp} 2$ 의 역할}

발생 중인 마우스 코티기관에서는 $\mathrm{Bmp} 2$ 가 외유모세포 (OHC)에서 그리고 Bmp4가 Henson's and Claudius' cell에서 강하게 발현된다. ${ }^{3)} \mathrm{Bmp} 2$ 와 Bmp4는 Noggin과 $\mathrm{Bmp}$ receptor에 붙는데 비슷한 친화력(affinities) 가지고 있다고 알려져있다. ${ }^{42,43)}$ 그러므로 배양와우체(cochlear explant)에 Bmp4를 외부에서 넣어줄 때 생기는 외유모세포 $(\mathrm{OHC})$ 열의 증가는 $\mathrm{Bmp} 4$ 의 역할이거나 또는 $\mathrm{Bmp} 2$ 의 역할일 가능성이 있다. 와우에서 Bmp2의 발현은 E15.5$\mathrm{P} 1$ 동안에만 발현되지만 이 시기는 유모세포의 운명 (fate) 과 갯수를 결정하는 데 중요한 시기이고, 더군다나, 조류 (chicken)에서는 마우스와는 달리 유모세포에서 Bmp4가 발현한다는 것을 생각할때 마우스 외유모세포에서 발현되 는 $\mathrm{Bmp} 2$ 에 대한 분석은 중요한 가치가 있어 보인다.

하지만 Foxg1-cre 라인을 이용하여 Bmp2를 내이에서 delete 시켰을 때 코티기관의 구조변화는 관찰되지 않았다. ${ }^{3)}$ Foxg1-cre; Bmp $2^{\mathrm{lox} /}$ 마우스는 태어나자마자 죽기 때문 에 기능적인 검사 즉 청력검사를 시행하지 못하였다. 그래서 유모세포에서만 발현되는 Math1의 downstream gene 인 Gfi1-cre를 이용하여 유모세포에서 Bmp2를 제거하였으나 코티기관의 구조변화는 마찬가지로 관찰되지 않았고 또한 생후 3 개월에서의 청력검사상 이상 소견도 관찰되지 않았 으며 1 년간의 추적관찰에서도 조기청력감퇴 (premature presbycusis)가 관찰되지 않았다. ${ }^{3)}$ 이상의 결과에서 유추 해보면 코티기관의 신경외측(abneural side), 즉, Henson' $\mathrm{s}$ and Claudius' cells에 발현되는 Bmp4가 유모세포에서 발현되는 Bmp2보다 유모세포 열의 개수를 결정하는 데 있 어 중요하다는 것을 알 수 있다. 더군다나 $\mathrm{Bmp} 7^{-/-}$마우 스는 내이에 이상이 없는 것으로 알려져있고, ${ }^{44)}$ Noggin에 대한 친화력도 $\mathrm{Bmp} 2$ 나 $\mathrm{Bmp} 4$ 에 비해 약하다는 사실 ${ }^{43)}$ 은 $\mathrm{Bmp} 4$ 가 코티기관의 유모세포 개수를 결정하는 데 간여하 는 유일한 Bmp임을 가리킨다.

\section{코티기관 형성에서 $\mathrm{Fgfs}$ 와 $\mathrm{Bmps}$ 의 관계}

Fgf8, Fgf10 and Fgf20 같은 상당히 많은 종류의 FGF 가 코티기관의 발달 중에 발현된다. ${ }^{45-47)} \mathrm{Fgfr} 1$ (Fgf receptor1)의 conditional deletion시 와우관을 따라 감각세포섬 (patches of sensory islands)이 발견된다. ${ }^{48)}$ Fgf20은 감 각세포대(prosensory domain)에 발현되며 Fgfr1을 활성 화시키는 주신호전달체(main ligand)으로 알려져있다. ${ }^{47)}$ 또 한 전구감각세포군(prosensory domain)에 발현되는 Fgfr3 (Fgf receptor3)가 제거(deletion) 되었을 때는 pillar cells의 소실과 함께 외유모세포 $(\mathrm{OHC})$ 의 증가가 나타난다. ${ }^{39,49)}$ 또한 내유모세포(IHC)에서 분비되는 Fgf8는 Fgfr3을 활 성화시키는주신호전구체(main ligand) 로 알려져있다. ${ }^{45)}$

와우형성에 있어 $\mathrm{Fgf}$ 와 Bmp의 상호작용에 대한 가능성 은 Noggin을 외부에서 넣어줄 때 $\mathrm{Fgfr}^{-/-}$와우배양체(cochlear explant)의 표현형(phenotype)이 회복(rescue) 됨 을 관찰함으로써 제기되었다. ${ }^{39)} \mathrm{Fgfr}^{-/-}$와우배양체(cochlear explant)는 외유모세포 $(\mathrm{OHC})$ 열의 증가를 보이는 데 외부에서 Noggin을 주면 열의 수가 줄어든다. 이것은 증가된 $\mathrm{Bmp} 4$ 의 활성도가 $\mathrm{Fgfr} 3^{-/}$와우배양체(explant) 에서 보이는 늘어난 외유모세포 갯수증가의 원인임을 암시 한다. 이 결과는 또한 $\mathrm{Fgf}$ 가 $\mathrm{Bmp}$ 와의 상호작용을 통해 외유모세포의 갯수를 정한다는 것을 의미한다. ${ }^{39)}$

다른 조직들에서도 Fgf와 Bmp의 길항작용 (antagonistic relationships)은 보고된 바가 있다. ${ }^{50-52)} \mathrm{Bmp} 4$ 가 형 성하는 농도경사(gradient)는 전구감각세포군(prosensory domain)에 발현되는 Fgf10과 Fgf20이나 외유모세포(IHC) 에서 발현되는 Fgf8에 의해 좀 더 세밀한 조정(fine-tuned) 을 받을 것으로 생각된다. ${ }^{45-47)}$ 하지만 Fgf signaling의 변 화가 있는 $\mathrm{Fgfr}^{-/-}$나 Sprouty $2^{-/-}$마우스 등에서는 오직 외유모세포 열의 갯수만 영향을 받고 내유모세포 열의 변 화가 없다는 것은 아직 풀어야할 의문점이다. ${ }^{39,49,53)}$ 와우에 선 다양한 종류의 Fgf가 발현되므로 잉여기능분담(functional redundancy)이 그 이유 중의 하나로 생각되며, ${ }^{39,49)}$ 
앞으로의 연구는 Fgf와 Bmp가 어떤 방법으로 각기 다른 유모세포의 운명(fate)을 결정짓는가 하는 것에 맞추어져야 하겠다.

\section{결 론}

위에서 마우스의 세반고리관 형성과 코티기관의 형성에 대해 분자생물학적 측면에서 지금까지 보고된 바를 정리해 보았다. 내이의 발생은 각 단계별로 많은 유전자가 관여하 고 있으며 그 유전자의 상호작용은 결코 간단하지 않고 아 직도 밝혀지지 않은 부분이 훨씬 더 많다. 현재 우리가 하 는 연구는 어떤 특정 유전자의 결손 시에 어떤 관련 유전 자의 발현이 저하되는지 또는 어떤 유전자의 발현이 증가 하는지를 통해 유전자의 상하관계를 규명(epistasis)하는 단계에 머물어 있으며 앞으로도 더 많은 지식의 축적을 필 요로 한다. 이러한 난청과 기형을 유발시키는 유전자들에 대한 이해는 현재 답보상태에 있는 줄기세포연구나 유전자 치료 분야에 촉매제 역할을 하리라 기대하며 유전자 중심 으로 재편되는 임상환경을 이해하는 데 많은 도움을 줄 것 이라 기대한다.

\section{REFERENCES}

1) Jeffery N, Spoor F. Prenatal growth and development of the modern human labyrinth. J Anat 2004;204 (2) :71-92.

2) Hwang CH, Simeone A, Lai E, Wu DK. Foxg1 is required for proper separation and formation of sensory cristae during inner ear development. Dev Dyn 2009;238 (11):2725-34

3) Hwang CH, Guo D, Harris MA, Howard O, Mishina Y, Gan L, et al. Role of bone morphogenetic proteins on cochlear hair cell formation: analyses of Noggin and Bmp2 mutant mice. Dev Dyn 2010;239(2): 505-13.

4) Driver EC, Pryor SP, Hill P, Turner J, Rüther U, Biesecker LG, et al. Hedgehog signaling regulates sensory cell formation and auditory function in mice and humans. J Neurosci 2008;28 (29) :7350-8.

5) Gubbels SP, Woessner DW, Mitchell JC, Ricci AJ, Brigande JV. Functional auditory hair cells produced in the mammalian cochlea by in utero gene transfer. Nature 2008;455 (7212):537-41.

6) Fritzsch B. Development of inner ear afferent connections: forming primary neurons and connecting them to the developing sensory epithelia. Brain Res Bull 2003;60 (5-6) :423-33

7) Morsli H, Choo D, Ryan A, Johnson R, Wu DK. Development of the mouse inner ear and origin of its sensory organs. J Neurosci 1998;18 (9):3327-35.

8) Martin P, Swanson GJ. Descriptive and experimental analysis of the epithelial remodellings that control semicircular canal formation in the developing mouse inner ear. Dev Biol 1993;159(2):549-58.

9) Schoenwolf GC, Alvarez IS. Roles of neuroepithelial cell rearrangement and division in shaping of the avian neural plate. Development 1989;106 (3) :427-39.

10) Kinsella MG, Fitzharris TP. Control of cell migration in atrioventricular pads during chick early heart development: analysis of cushion tissue migration in vitro. Dev Biol 1982;91 (1):1-10

11) Ferguson MW. Palate development. Development 1988;103 Suppl:
41-60.

12) Haddon CM, Lewis JH. Hyaluronan as a propellant for epithelial movement: the development of semicircular canals in the inner ear of Xenopus. Development 1991;112 (2):541-50.

13) McPhee JR, Van de Water TR, Su HX. Hyaluronate production by the inner ear during otic capsule and perilymphatic space formation. Am J Otolaryngol 1987;8 (5):265-72.

14) Tien JY, Spicer AP. Three vertebrate hyaluronan synthases are expressed during mouse development in distinct spatial and temporal patterns. Dev Dyn 2005;233 (1) :130-41.

15) Waterman RE, Bell DH. Epithelial fusion during early semicircular canal formation in the embryonic zebrafish, Brachydanio rerio. Anat Rec 1984;210(1):101-14.

16) Fekete DM, Homburger SA, Waring MT, Riedl AE, Garcia LF. Involvement of programmed cell death in morphogenesis of the vertebrate inner ear. Development 1997;124 (12) :2451-61.

17) Kobayashi Y, Nakamura H, Funahashi J. Epithelial-mesenchymal transition as a possible mechanism of semicircular canal morphogenesis in chick inner ear. Tohoku J Exp Med 2008;215 (3) :207-17.

18) Chen P, Segil N. p27 (Kip1) links cell proliferation to morphogenesis in the developing organ of Corti. Development 1999;126 (8):1581-90.

19) Kelley MW. Cellular commitment and differentiation in the organ of Corti. Int J Dev Biol 2007;51 (6-7) :571-83.

20) Doetzlhofer A, Basch ML, Ohyama T, Gessler M, Groves AK, Segil $\mathrm{N}$. Hey2 regulation by FGF provides a Notch-independent mechanism for maintaining pillar cell fate in the organ of Corti. Dev Cell 2009;16(1):58-69.

21) von Bubnoff $\mathrm{A}$, Cho $\mathrm{KW}$, Intracellular BMP signaling regulation in vertebrates: pathway or network? Dev Biol 2001;239(1):1-14.

22) Balemans W, Van Hul W, Extracellular regulation of BMP signaling in vertebrates: a cocktail of modulators. Dev Biol 2002;250 (2):231-50.

23) Holley SA, Neul JL, Attisano L, Wrana JL, Sasai Y, O’Connor MB, et al. The Xenopus dorsalizing factor noggin ventralizes Drosophila embryos by preventing DPP from activating its receptor. Cell 1996; $86(4): 607-17$

24) Piccolo S, Sasai Y, Lu B, De Robertis EM. Dorsoventral patterning in Xenopus: inhibition of ventral signals by direct binding of chordin to BMP-4. Cell 1996;86 (4):589-98.

25) Davis SW, Camper SA. Noggin regulates Bmp4 activity during pituitary induction. Dev Biol 2007;305 (1):145-60.

26) Brunet LJ, McMahon JA, McMahon AP, Harland RM. Noggin, cartilage morphogenesis, and joint formation in the mammalian skeleton. Science 1998;280 (5368):1455-7.

27) Hwang $\mathrm{CH}, \mathrm{Wu} \mathrm{DK}$. Noggin heterozygous mice: an animal model for congenital conductive hearing loss in humans. Hum Mol Genet 2008;17 (6):844-53.

28) Keller R. Shaping the vertebrate body plan by polarized embryonic cell movements. Science 2002;298 (5600):1950-4.

29) Yamamoto N, Okano T, Ma X, Adelstein RS, Kelley MW. Myosin II regulates extension, growth and patterning in the mammalian cochlear duct. Development 2009;136 (12):1977-86.

30) McKenzie E, Krupin A, Kelley MW. Cellular growth and rearrangement during the development of the mammalian organ of Corti. Dev Dyn 2004;229 (4):802-12.

31) Wang J, Mark S, Zhang X, Qian D, Yoo SJ, Radde-Gallwitz K, et al. Regulation of polarized extension and planar cell polarity in the cochlea by the vertebrate PCP pathway. Nat Genet 2005;37 (9) :980-5.

32) Simons M, Mlodzik M. Planar cell polarity signaling: from fly development to human disease. Annu Rev Genet 2008;42:517-40.

33) Qian D, Jones C, Rzadzinska A, Mark S, Zhang X, Steel KP, et al. Wnt5a functions in planar cell polarity regulation in mice. Dev Biol 2007;306 (1):121-33.

34) Montcouquiol M, Kelley MW. Planar and vertical signals control cellular differentiation and patterning in the mammalian cochlea. J Neurosci 2003;23 (28):9469-78. 
35) Montcouquiol M, Rachel RA, Lanford PJ, Copeland NG, Jenkins NA, Kelley MW. Identification of Vang12 and Scrb1 as planar polarity genes in mammals. Nature 2003;423 (6936):173-7.

36) Bok J, Brunet LJ, Howard O, Burton Q, Wu DK. Role of hindbrain in inner ear morphogenesis: analysis of Noggin knockout mice. Dev Biol 2007;311 (1):69-78.

37) Koo SK, Hill JK, Hwang CH, Lin ZS, Millen KJ, Wu DK. Lmx1a maintains proper neurogenic, sensory and non-sensory domains in the mammalian inner ear. Dev Biol 2009;333 (1):14-25.

38) Li H, Corrales CE, Wang Z, Zhao Y, Wang Y, Liu H, et al. BMP4 signaling is involved in the generation of inner ear sensory epithelia. BMC Dev Biol 2005;5:16.

39) Puligilla C, Feng F, Ishikawa K, Bertuzzi S, Dabdoub A, Griffith AJ, et al. Disruption of fibroblast growth factor receptor 3 signaling results in defects in cellular differentiation, neuronal patterning, and hearing impairment. Dev Dyn 2007;236 (7):1905-17.

40) Pujades C, Kamaid A, Alsina B, Giraldez F. BMP-signaling regulates the generation of hair-cells. Dev Biol 2006;292 (1):55-67.

41) Chang W, Lin Z, Kulessa H, Hebert J, Hogan BL, Wu DK. Bmp4 is essential for the formation of the vestibular apparatus that detects angular head movements. PLoS Genet 2008;4 (4) :e1000050.

42) Rosen V, Thies RS, Lyons K, Signaling pathways in skeletal formation: a role for BMP receptors. Ann N Y Acad Sci 1996;785:59-69.

43) Zimmerman LB, De Jesús-Escobar JM, Harland RM. The Spemann organizer signal noggin binds and inactivates bone morphogenetic protein 4. Cell 1996;86 (4):599-606.

44) Karsenty G, Luo G, Hofmann C, Bradley A. BMP 7 is required for nephrogenesis, eye development, and skeletal patterning. Ann N Y Acad Sci 1996;785:98-107.
45) Jacques BE, Montcouquiol ME, Layman EM, Lewandoski M, Kelley MW. Fgf8 induces pillar cell fate and regulates cellular patterning in the mammalian cochlea. Development 2007;134 (16) :3021-9.

46) Pauley S, Wright TJ, Pirvola U, Ornitz D, Beisel K, Fritzsch B. Expression and function of FGF10 in mammalian inner ear development. Dev Dyn 2003;227 (2) :203-15.

47) Hayashi T, Ray CA, Bermingham-McDonogh O. Fgf20 is required for sensory epithelial specification in the developing cochlea. J Neurosci 2008;28(23) :5991-9.

48) Pirvola U, Ylikoski J, Trokovic R, Hébert JM, McConnell SK, Partanen J. FGFR1 is required for the development of the auditory sensory epithelium. Neuron 2002;35 (4):671-80

49) Hayashi T, Cunningham D, Bermingham-McDonogh O. Loss of Fgfr3 leads to excess hair cell development in the mouse organ of Corti. Dev Dyn 2007;236 (2):525-33.

50) Huang J, Dattilo LK, Rajagopal R, Liu Y, Kaartinen V, Mishina Y, et al. FGF-regulated BMP signaling is required for eyelid closure and to specify conjunctival epithelial cell fate. Development 2009;136(10): 1741-50.

51) Cushing MC, Mariner PD, Liao JT, Sims EA, Anseth KS. Fibroblast growth factor represses Smad-mediated myofibroblast activation in aortic valvular interstitial cells. FASEB J 2008;22 (6):1769-77.

52) Pera EM, Ikeda A, Eivers E, De Robertis EM. Integration of IGF, FGF, and anti-BMP signals via Smad1 phosphorylation in neural induction. Genes Dev 2003;17 (24):3023-8.

53) Shim K, Minowada G, Coling DE, Martin GR. Sprouty2, a mouse deafness gene, regulates cell fate decisions in the auditory sensory epithelium by antagonizing FGF signaling. Dev Cell 2005;8 (4):553-64. 